\title{
A NOVEL METHOD FOR PRODUCING A GLULAM FROM THE WOOD OF PEELER CORES
}

\author{
Daniel Koynov ${ }^{1}$ \\ https://orcid.org/0000-0001-5370-9468 \\ Rosen Grigorov ${ }^{l}$ \\ https://orcid.org/0000-0001-7922-0855 \\ Miglena Valyova ${ }^{2,4}$ \\ https://orcid.org/0000-0003-4072-2537
}

\begin{abstract}
This study presents an opportunity for rational utilization of poplar wood peeler cores in the production of glued laminated timber (glulam) beams. An approach for optimal use of small-diameter raw material with a circular cross-section is also proposed in order to obtain a final product in a significantly high quantitative yield. The applied novel method of sawing the peeler cores and subsequent combination of gluing the obtained lamellas allows to achieve: reduction of labor and energy consumption in the processing; rational utilization of this waste raw material; obtaining a product sought by consumers; opportunity to implement technology for the production of glulam from peeler cores. The results showed that sawing the peeler cores and obtaining lamellas with a trapezoidal cross-section leads to a high quantitative yield of $76,3 \%$. The final quantitative yield in subsequent technological operations in the manufacturing of engineered wood of glulam type reaches $48,8 \%$ of the volume of raw material. In addition, equations have been working are used for the determination of the most suitable sizes of the lamellas, depending on the diameter and the kerf width.
\end{abstract}

Keywords: Engineered wood, glulam, peeler cores, Populus sp., small-diameter logs.

\section{INTRODUCTION}

The yield of wood in the woodworking production depends mainly on the market requirements, quality of the raw material and sawing method. The ability to utilization of the wood waste, generated in the process of developing or sawing logs in the most optimal way possible will contribute to higher economic results. Therefore, the approach for sawing the raw material is of particular importance, especially for small-diameter assortments.

The production of veneer and plywood is a result of the desire for rational use and improvement of the properties of wood materials (Wiedenbeck et al. 2003, Bal and Bektaş 2014, Muñoz and Moya 2018, Réh et al. 2019, Lengowski et al. 2020, Réh et al. 2021). One of the largest manufacturers of plywood in Bulgaria is „Welde Bulgaria“ company, Troyan. Poplar wood and less often other wood species, including beech are mainly used as raw material for developed veneer.

\footnotetext{
${ }^{1}$ University of Forestry, Faculty of Forest Industry, Department of Mechanical Technology of Wood. Sofia, Bulgaria.

${ }^{2}$ University of Forestry, Faculty of Ecology and Landscape Architecture, Department of Plant Pathology and Chemistry. Sofia, Bulgaria. •Corresponding author: mvalyova@abv.bg

Received: 27.12.2020 Accepted: 21.09.2021
} 
The distribution of the afforested area in hectares (Executive Forest Agency 2015) of these species in Bulgaria is the following: Populus sp. - 23 thousand ha and Fagus sylvatica L. - 160 thousand ha. The distribution of wood stock in cubic meters until 2015 is as follows: Populus sp. - 3 million $\mathrm{m}^{3}$ and Fagus sylvatica L. - 33 million $\mathrm{m}^{3}$, respectively. According to a forest management project, approximately 300 thousand $\mathrm{m}^{3}$ of dense mass is harvested from the poplar wood every year.

Poplars are fast-growing tree species, and their wood is soft, light and elastic. It dries and shrinks a little and is very easy to process (Castro and Fragnelli 2006). The poplar wood possesses a relatively low density $\left(300 \mathrm{~kg} \cdot \mathrm{m}^{-3}-390 \mathrm{~kg} \cdot \mathrm{m}^{-3}\right)$. The physical and mechanical properties of this wood are relatively low compared to the most commonly used wood species in the industry. However, their bending strength can be compared to that of spruce, pine and fir wood (Balatinecz and Kretschmann 2001, Sinković et al. 2017). This gives a precondition for the products obtained from this wood species to compete with the similar products from spruce, fir and pine.

In the process of developing the logs and extracting the veneer sheet, a significant amount of wood waste, veneer pieces and peeler cores is inevitably obtained. Due to the growing shortage of wood raw materials, there is a need for rational and comprehensive utilization of residual products from a given production (Tenorio et al. 2011, Antov and Savov 2019). The utilization of peeler cores in the enterprises in our country has found application mainly for the production of pallets, packaging and other products supporting the technological process.

The traditional sawing methods for small-diameter round wood assortments, which are most often used in the woodworking production, show a low efficiency of the machines and quantitative yield (Loginova 1999, Starkova 2004, Heräjärvi et al. 2004, Hernandez et al. 2005, Campbell 2013). Therefore, improving the sawing efficiency of this raw material will create an opportunity to reduce the production costs.

In contrast to the logs that are shaped similar to a truncated cone, the peeler cores are with almost perfect geometrical shape similar to that of the cylinder. Therefore, the sawing of the peeler cores, will avoid the consumption of wood due to the irregular shape of the cross- section, taperingness zone and curves of the tree trunk. These disadvantages have a significant negative impact on the final quantitative yield, especially at the small-diameter round assortments.

The raw material used for the production of plywood is of very high quality, which leads to the absence or maximum limitation of defects in the wood. The area from which the peeler cores are obtained is in the approximately geometric center of the logs, which is also a factor in the absence of knots and other defects, except of a core. The presence of defects in the wood in the manufacturing of engineered wood has a significant effect on the final quantitative yield. It is clear that in the central part of the logs, as well as those with a small diameter, there is a significant amount of juvenile wood and this will affect their physical and mechanical properties (Yang 1994, Zobel and Sprague 1998).

The introduction of appropriate methods for sawing and subsequent gluing in order to obtain a product that meets the needs of consumers will lead to a more rational and complex utilization of raw materials, reducing the volume of wood waste and obtaining a qualitative product for buyers.

\section{MATERIAL AND METHODS}

In our research, poplar wood peeler cores (Populus sp.), obtained in the production of plywood was used (Figure 1). The dimensional characteristics and the volume of the samples were measured. The quantitative yield of solid wood materials was calculated as a ratio of the volume of round wood assortments from which they were obtained. Several sawing methods of small-diameter logs were compared and the most optimal one for the needs of the research was chosen. An effective method for processing and subsequent gluing was also adopted, in order to obtain a product from engineered wood (glulam) in higher quantitative yield. 


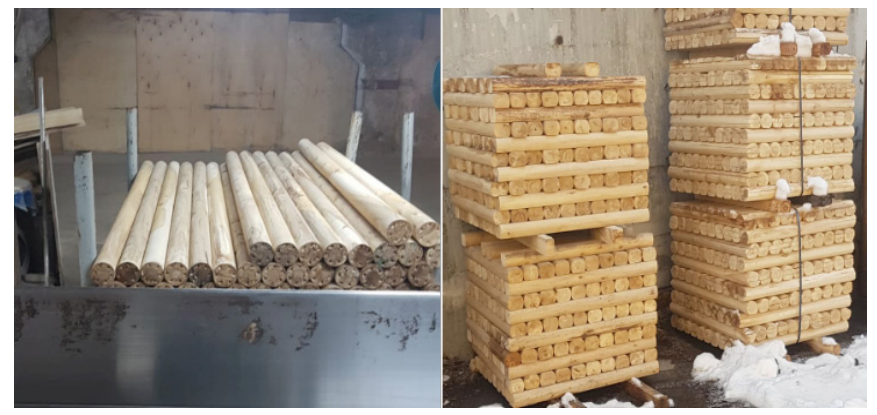

Figure 1: Peeler cores from the poplar wood.

Rongrong et al. (2015) considered different sawing methods of small-diameter round wood assortments $80 \mathrm{~mm}, 100 \mathrm{~mm}$ and $120 \mathrm{~mm}$, respectively. They found that the average quantitative yields reached following values: $R=53,3 \%$ for live sawing, $R=56,7 \%$ for triangle sawing- $R=63,2 \%$ for trapezoidal sawing and $\mathrm{R}$ $=82,7 \%$ for hexagon sawing, respectively.

In the present study, four peeler cores with an approximate diameter of $100 \mathrm{~mm}$ were used in order to obtain one glulam beam. They are left to air dry for several months. After reaching equilibrium humidity $(H$ $\approx 20 \%$ ), the peeler cores were cut longitudinally into two semicircles using a circular saw (Figure 2-1). The produced materials were dried in a laboratory convection dryer $(H=8 \%)$. In order to calibrate and obtain two parallel sides, the planer was used. The obtained wood lamellas were with shrinkage allowance for subsequent mechanical processing. To establish the actual quantitative yields in the production of a glulam beam, fingerjoints were cut in the fronts of the lamellas and subsequently spliced lengthwise. The trapezoidal cross-section of the lamellas was formed by means of a circular machine with the possibility of tilting the shaft at a certain angle. In this way, from one peeler core, which after drying reaches dimensions in diameter of $96 \mathrm{~mm}$, two lamellas with trapezoidal cross-section were produced. Their dimensions are as follows: wide base- $b_{1} \approx 95$ $\mathrm{mm}$, small base- $b_{2} \approx 50 \mathrm{~mm}$, height- $h \approx 39 \mathrm{~mm}$, as well as angle between base and sides- $60^{\circ}$ (Figure 2-2).

Figure 2 illustrates the sequence of sawing of peeler cores in order to obtain solid wood materials with a maximum trapezoidal cross-sectional size, included in half of a circle. The kerf width was assumed to be $3 \mathrm{~mm}$.

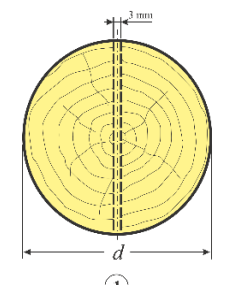

(1)

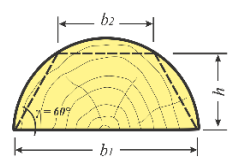

(2)

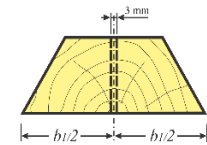

(3)

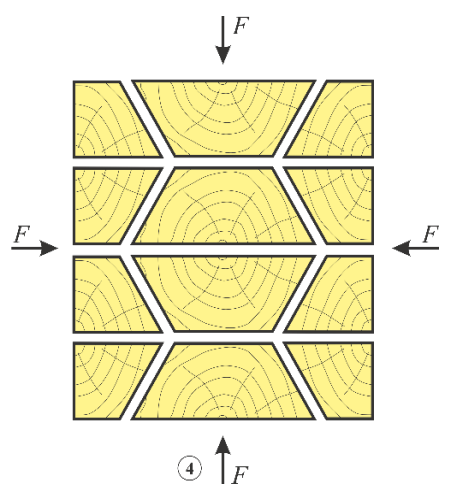

Figure 2: Sawing method for peeler cores and obtaining of glulam.

With the applied method of sawing from two peeler cores, four lamellas with a trapezoidal cross-section, which form the central part of glulam were obtained. The other two peeler cores after formation of the lamellas were cut into two halves (Figure 2-3). The lamellas received by this method form the outer parts of glulam (Figure 2-4). After gluing and arranging the adhesive package, it was pressed to obtain a final product with a rectangular cross-section.

The accepted method for sawing of peeler cores and the subsequent gluing of the lamellas to obtain glulam 
was applied in laboratory conditions (Figure 3).

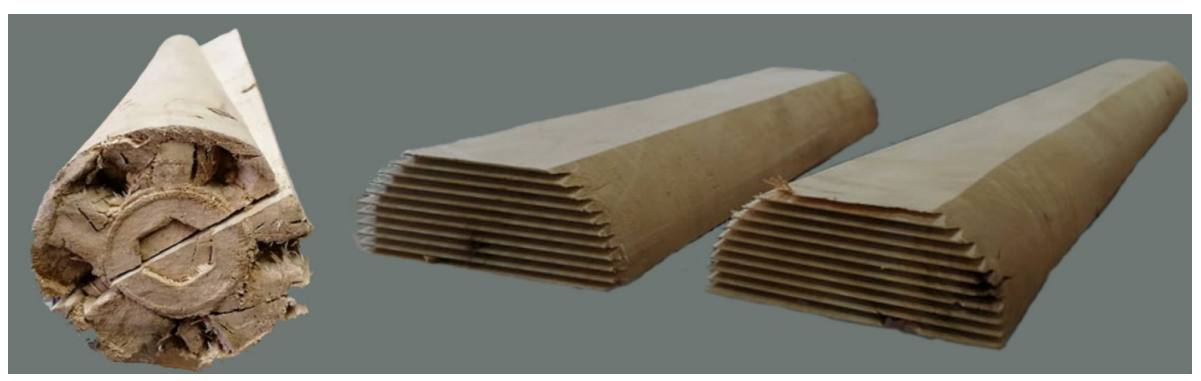

Figure 3: Test specimens of peeler cores lamellas for the production of glulam.

Polyvinyl acetate (PVAc) adhesive for gluing of the wood was used. Depending on the performance of these products, other adhesives can be used (Frihart 2015, Ogunsanwo et al. 2019, Petkov and Mihailov 2019, de Oliveira et al. 2020, Petkov and Mihailov 2020, Antov et al. 2020a, Antov et al. 2020b, Yusof et al. 2021).

The method for determining the optimal dimensions of the trapezoidal cross-sections is based on the trigonometric dependences resulting from an inscribed regular hexagon in a circle. They are presented in Figure 4.
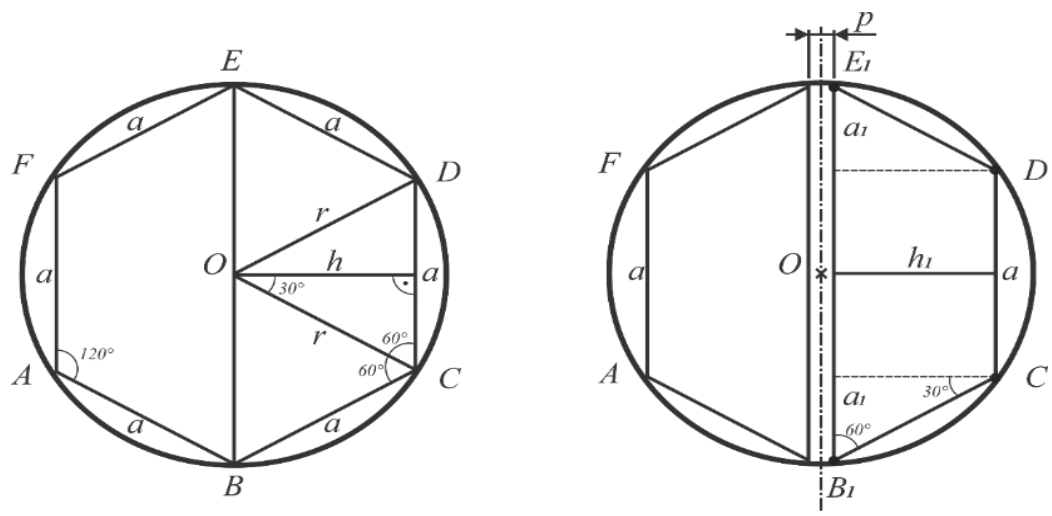

Figure 4: Regular hexagon inscribed in a circle and a kerf passing through its geometric center.

Several equations were used for proposing of the most optimal dimensions of the trapezoidal cross-sections, based on the dependence between the diameter and width of the kerf (Equation 1, Equation 2, Equation 3, Equation 4):

$$
\begin{aligned}
& r=a \\
& h=\frac{r \sqrt{3}}{2} \\
& h_{1}=\frac{r \sqrt{3-p}}{2}
\end{aligned}
$$




$$
B_{1} E_{1}=\frac{3 r-p \sqrt{3}}{3}
$$

Where:

$r$ - radius of the peeler core

$a$ - side of a hexagon inscribed in a circle

$p$ - kerf width

$h_{1}$ - thickness of the board depending on the diameter of the peeler core

According to the accepted methodology in laboratory conditions glulam with final cross-sectional dimensions - $126 \mathrm{~mm} \times 131 \mathrm{~mm}$ was obtained (Figure 5).
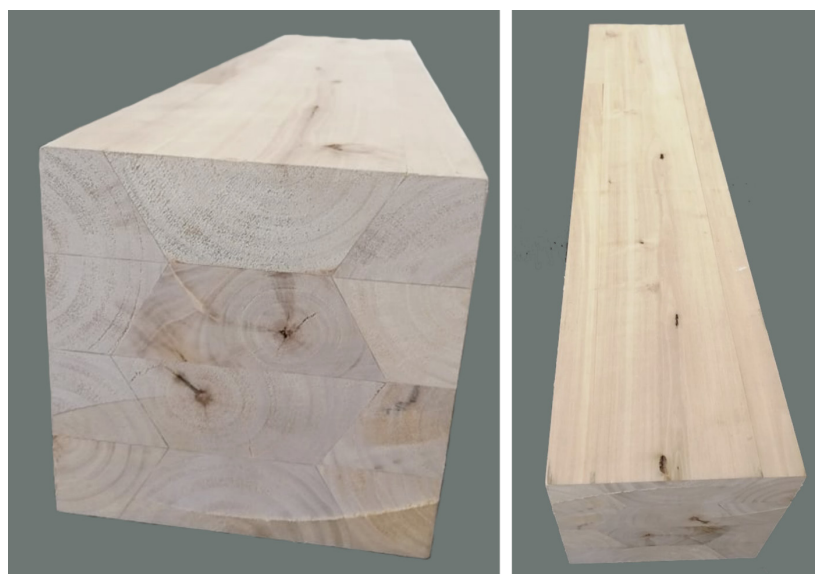

Figure 5: Glulam type glued beams.

\section{RESULTS AND DISCUSSION}

In the process of veneer development, a peeler cores with a final diameter is inevitably received, depending on the available technology of the enterprise. Their utilization is not very rational, as the peeler cores are applied mainly in the production of pallets, packaging, technological chips, raw materials for combustion and others.

According to approximate data from "Welde Bulgaria" AD company, more than 2 thousand $\mathrm{m}^{3}$ of wood in the form of peeler cores is discarded all year round. This represents a serious raw material potential for rational recycling of this waste wood in glulam manufacturing. In the present research, poplar wood peeler cores were used, as the company mainly processes this wood species in the production of plywood. The method of processing peeler cores, lamellas and obtaining glulam can also be used for peeler cores from other tree species.

According to the literature data, there is no research work that deals comprehensively with the production of glulam by utilizing the peeler cores and small-diameter round wood according to the proposed methodology. A minimum of four peeler cores are required to obtain a beam with the attached cross-section. It is possible to form a beam with a larger cross-section depending on the needs. The only condition for receiving such a 
beam is that the outer parts of glulam are formed by the respective halves of the lamellas with a trapezoidal cross- section.

The theoretical quantitative yield by sawing of the peeler cores of two prisms with a trapezoidal cross section reach a value of $R=78,2 \%$. The experimentally established results showed a quantitative yield of $R=$ $76,3 \%$. This difference is due to the minimal loss of wood because of inaccurate centering during processing, as well as slight curves occurred after drying of the peeler cores.

Moreover, the applied method provides an opportunity to obtain a product with a rectangular cross-section and the expected dimensions according to the needs of consumers. The technology for producing such a product is the same as for the obtaining of glulam.

The experimentally established high quantitative yield of the received glulam beams from lamellas with trapezoidal cross-section reaches $R=48,8 \%$ of the initial peeler cores volume. This is due to the fact that a technological operation is omitted - removal of knots and other defects. At this operation, a large amount of wood is cut, which significantly reduces the final quantitative yield. In many cases in the manufacturing of engineered wood, depending on the quality of the raw material, the final quantitative yield is twice less than presented in this study.

The results obtained show that this method is particularly suitable for the processing of both peeler cores and small-diameter round wood. In this way the latter can be used extremely rationally in the production of the final product sought by consumers.

\section{CONCLUSIONS}

The proposed methodology for obtaining lamellas with a trapezoidal cross-section aims maximum utilization of the small-diameter round wood volume.

An opportunity for rational application of the peeler cores, which inevitably occurs during the development of veneer, was offered.

A method for producing a product with a rectangular or square cross-section from peeler cores at a significantly high quantitative yield was presented.

The formation of the trapezoidal cross-section of the lamellas can be done with a four-sided planer. This will shorten several technological operations. At the same time, all lamellas will have accurate cross-sectional dimensions and the duration of the technological process will be reduced.

In the described method for the production of glulam, inconvenience arises due to the fact that not all lamellas have trapezoidal cross-sections. This in turn will lead to difficulties in forming the adhesive package. On the other hand, the technology for gluing the lamellas will be difficult. In addition, the implementation of proper organization will eliminate the mentioned inconveniences.

In order to establish the physical and mechanical properties of the resulting glulam from lamellas with trapezoidal cross section, additional tests will be conducted.

\section{ACKNOWLEDGMENTS}

The authors wish to thank "Welde Bulgaria" AD company for providing the raw materials. 


\section{REFERENCES}

Antov, P.; Savov, V. 2019. Possibilities for manufacturing eco-friendly medium density fibreboards from recycled fibres - a Review. In Proceedings of the 30th International Conference on Wood Science and Technology- ICWST 2019, 12-13 December 2019, Zagreb, Croatia. p.18-24. https://core.ac.uk/download/ pdf/288163581.pdf\#page $=31$.

Antov, P.; Savov, V.; Neykov, N. 2020a. Sustainable bio-based adhesives for eco-friendly wood composites. A Review. Wood Res-Slovakia 65(1): 51-62. https://dx.doi.org/10.37763/wr.1336-4561/65.1.051062.

Antov, P.; Savov, V.; Neykov, N. 2020b. Reduction of formaldehyde emission from engineered wood panels by formaldehyde scavengers - a Review. In Proceedings of 13th International Scientific Conference WoodEMA 2020 and 31-st International Scientific

Bal, B.C.; Bektaş, İ. 2014. Some mechanical properties of plywood produced from eucalyptus, beech, and poplar veneer. Maderas-Cienc Tecnol 16(1): 99-108. https://dx.doi.org/10.4067/S0718-221X2014005000009

Balatinecz, J.J.; Kretschmann, D.E. 2001. Properties and utilization of poplar wood. In Poplar Culture in North America. Part A. Chapter 9: 277-291. NRC Research Press, National Research Council of Canada, Ottawa, ON KIA OR6, Canada. https://www.fs.usda.gov/treesearch/pubs/8597_

Campbell, E. 2013. Simulation of sawmill yields at Hyne Tuan pine mill. Ph.D. Thesis, University of Southern QLD, Australia. https://eprints.usq.edu.au/24656/1/Campbell_2013.pdf.

Castro, G.; Fragnelli, G. 2006. New technologies and alternative uses for poplar wood. Boletín Informativo CIDEU 2: 27-36. https://dialnet.unirioja.es/servlet/articulo?codigo=2258287_

Executive Forest Agency. 2015. Annual report on the afforested area until December 31, 2015. Forest fund of Bulgaria: forms 2, 3 and 5.

Frihart, C.R. 2015. Introduction to Special Issue: Wood Adhesives: past, present, and future. Forest Prod $J$ 65(1-2): 4-8. https://doi.org/10.13073/65.1-2.4.

Heräjärvi, H.; Jouhiaho, A.; Tammiruusu, V.; Verkasalo, E. 2004. Small-diameter Scots pine and birch timber as raw materials for engineered wood products. Int J For Eng 15(2): 23-34. https://doi.org/10.1080/14 942119.2004.10702494.

Hernandez, R.; Green,W.; Kretschmann, E.; Verrill, P. 2005. Improved utilization of small-diameter ponderosa pine in glulam timber. Res. Pap. FPL-RP-625. Madison, WI: U.S. Department of Agriculture, Forest Service, Forest Products Laboratory. https://doi.org/10.2737/FPL-RP-625.

Lengowski, E.C.; Bonfatti Júnior, E.A.; Dallo, R.; Nisgoski, S.; Monteiro de Mattos, J.L.; Prata, J.G. 2020. Nanocellulose-reinforced phenol-formaldehyde resin for plywood panel production. Maderas-Cienc Tecnol 23: 1-10. https://doi.org/10.4067/s0718-221x2021000100405.

Loginova, G.A. 1999. Improving the production efficiency of thin wood material with increased demand. Ph.D. Thesis, Siberian State Technological University. Krasnoyarsk, Russia (In Russian). https://www. dissercat.com/content/povyshenie-effektivnosti-proizvodstva-tonkikh-pilomaterialov-povyshennogo-sprosa.

Muñoz, F.; Moya, R. 2018. Effect of nanoclay-treated UF resin on the physical and mechanical properties of plywood manufactured with wood from tropical fast growth plantations. Maderas-Cienc Tecnol 20(1): 1124 http://dx.doi.org/10.4067/S0718-221X2018005001202

Ogunsanwo, O. Yekin; Adenaiya, A.O.; Adedeji, C.A. 2019. Effect of adhesive quantity on selected physico-mechanical properties of Bamboo glulam. Maderas-Cienc Tecnol 21(1): 113-122. https://dx.doi.org/10.4067/S0718-221X2019005000111

Oliveira de, R.G.E.; Gonçalves, F.G.; Segundinho, P.G. de A.; Oliveira, J.T. da S.; Paes, J.B.; Chaves, I.L.S.; Brito, A.S. 2020. Analysis of glue line and correlations between density and anatomical characteristics of Eucalyptus grandis $\times$ Eucalyptus urophylla glulam. Maderas-Cienc Tecnol 22(4): 495-504. https://dx.doi.org/10.4067/S0718-221X2020005000408.

Petkov, T.; Mihailov, V. 2019. Study of lightweight beams made from wood with double t section - Ibeams. The Journal of Management and Sustainable Development 79(6): 105-110. (In Bulgarian). 
Petkov, T.; Mihailov, V. 2020. Influence of the applied pressure on finger joined end-to-end wood. Innovation in Woodworking Industry and Engineering Design IX (1): 16-20. http://www.scjournal-inno.com/ en/article-363.htm\#dl365.

Réh, R.; Igaz, R.; Krišt’ák, L.; Ružiak, I.; Gajtanska, M.; Božíková, M.; Kučerka, M. 2019. Functionality of beech bark in adhesive mixtures used in plywood and its effect on the stability associated with material systems. Materials 12: 1298. https://doi.org/10.3390/ma12081298.

Réh, R.; Krišt’ák, L.; Sedliačik, J.; Bekhta, P.; Božiková, M.; Kunecová, D.; Vozárová, V.; Tudor, E.M.; Antov, P.; Savov, V. 2021. Utilization of birch bark as an eco-friendly filler in urea-formaldehyde adhesives for plywood manufacturing. Polymers 13: 511. https://doi.org/10.3390/polym13040511.

Rongrong, L.; Pingxiang, C.; Xiaolei, G.; Futang, J.; Ekevad, M.; Wang, X.A. 2015. Novel sawing method for small-diameter log. Wood Res-Slovakia 60(2): 293-300. http://www.woodresearch.sk/ wr/201502/13.pdf.

Sinković, T.; Jambreković, B.; Šefc, B.; Ištok, I.; Veseličić, F.; Sedlar, T. 2017. Some physical and mechanical properties of white poplar (Populus alba L.) wood grown in Varaždin region. In Proceedings of $28^{\text {th }}$ International Conference on Wood Science and Technology. 7-8 December 2017. Zagreb, Croatia. pp. 101-106. https://www.bib.irb.hr/914647.

Starkova, A.V. 2004. Improving the technology for the production of shaped round timber blanks. Ph.D. Thesis, Arkhangelsk State Technical University. Arkhangelsk, Russia. https:/www.dissercat.com/content/ sovershenstvovanie-tekhnologii-proizvodstva-profilnykh-zagotovok-iz-kruglykh-lesomaterialov (In Russian).

Tenorio, C.; Moya, R.; Munoz, F. 2011. Comparative study on physical and mechanical properties of laminated veneer lumber and plywood panels made of wood from fast-growing Gmelina arborea trees. $J$ Wood Sci 57: 134-139. https://doi.org/10.1007/s10086-010-1149-7.

Wiedenbeck, J.; Wiemann, M.; Alderman, D.; Baumgras, J.; Luppold, W. 2003. Defining hardwood veneer $\log$ quality attributes. Gen. Tech. Rep. NE-313. Newtown Square, PA: U.S. Department of Agriculture, Forest Service, Northeastern Research Station. p.36. https://doi.org/10.2737/NE-GTR-313.

Yang, K.C. 1994. Impact of spacing on width and basal area of juvenile and mature wood in Picea mariana and Picea glauca. Wood Fiber Sci 26(4): 479-488. https://wfs.swst.org/index.php/wfs/article/view/818.

Yusof, N.M.; Tahir, P.M.; Lee, S.H.; Sabaruddin, F.A.; James, R.M.S.; Khan, M.A.; Lee, C.H.; Roseley, A.S.M. 2021. Thermal properties of Acacia mangium Cross Laminated Timber and its gluelines bonded with two structural adhesives. Maderas-Cienc Tecnol 23(2): 1-10. https://dx.doi.org/10.4067/s0718$221 \times 2021000100402$.

Zobel, B.J.; Sprague, J.R. 1998. Characteristics of Juvenile Wood. In: Juvenile Wood in Forest Trees. Springer Series in Wood Science: Berlin, Heidelberg. https://doi.org/10.1007/978-3-642-72126-7_2. 